document a few weeks ago (Nature 20 September, p. 193) some university administrators and their academic colleagues have indulged the fancy that the government is about to relent. What has happened is simply that the grants committee has taken a more robust view than in recent years of the universities' problems, and declared itself sympathetic to their needs. Specifically, it has made it plain that it does not passively accept that the universities can bend ever more pliantly to the government's demands (to train more engineers, for example) on a fixed budget. But as the experience of recent years has shown, even the strongest case may not prevail against a government strapped for cash. Lord Flowers, chairman of the Committee of Vice-Chancellors and Principals, was right to remind his constituents a week ago that this is not a "battle won, but a battle joined".

Euphoria is contagious, but dangerous. The debate arranged for 25 October in the House of Commons, on which many hopes are pinned, is almost certain to be a disappointment for the universities. Having lost their political friends in the 1970s, they are unlikely to be much comforted if the government's political opponents seize on what has been done to them as yet another stick with which to beat the administration over the head; or if, as seems likely, the government disarms criticism of its handling of British higher education in the past five years by a show of generosity, perhaps by promising an increase of the budget for university equipment. The test that those in higher education should apply to what is said in the House of Commons is that of whether the debate reveals an understanding that higher education (not just in universities) is a national resource and an economic and social necessity, not just a way of insulating a bunch of academic layabouts from the rigours of the labour market. (Tenure irrationally remains everybody's bête noire.)

Meanwhile, the universities have work of their own to do. The grants committee's document is rhetorically encouraging but full of pitfalls for the unwary or the indolent. Thus nothing substantial is said about the chief iniquity of the past three years - the imposition of student quotas that individual universities might exceed only at the risk of being penalized financially. The inference is that the grants committee will not in future enforce the rules its predecessor committee promulgated, which is a welcome development. The result should be that many universities will be able to make more economical use of the resources at their disposal by allowing departments starved of students to operate at full capacity. The snag, also only implicit in what the grants committee says, is that individual institutions will find themselves engaged in a complicated attempt to second-guess the grants committee. Taking in more students may help financially, if only at the margin, but may hazard an institution's capacity to compete for research support in future, but under a set of rules that has yet to be defined.

The issue is complicated and potentially contentious. The grants committee acknowledges, perhaps even overestimates, the importance of its financial support to the conduct of academic research in Britain. And now, when it is generally agreed that the dual mechanism of research support (from the committee and, in parallel, by means of project grants from research councils) has broken down, the committee says that it will in future be more discriminating between universities. All that makes sense, if only because, on paper, the present system provides all institutions with the general support that should enable them to compete for project grants in circumstances in which it is also generally understood that some are more able to compete successfully than others. Indeed, the grants committee has, over the years, implicitly trimmed its sails to this wind by being more generous to some universities than others while declining to say why, no doubt in the knowledge of the ructions there would be if universities had grounds for thinking that research support was being "earmarked", a synonym for the act of telling universities what to do and thus a gross intrusion into academic freedom.

So by what criteria will the grants committee discriminate among British universities in the provision of research support? By all accounts, the question has not been settled. All that the committee has said in public is that it will devise criteria that are distinct from those followed by the research councils in their provision of (mostly) project grants. Obviously that makes sense, for otherwise it would be just as well to replace the research councils as a whole by the grants committee. But what other yardsticks than peer-review, and a general sense of "timeliness and promise", can there be?

Here is one interesting and subversive way in which the grants committee might choose to solve the problem it has set itself. Why not, to begin with, take universities' own estimation of the reasons why they deserve research support? At first, the result would be that universities would share the research component of the grants committee's budget in much the same proportions as at present, and so might be tempted to assume that nothing had changed. But in making a case for research support, the prudent among them would be compelled to explain why their research proposals should be taken seriously. And the consequences of that could be enlivening. For it would turn out that universities that were capable internally of discriminating between good and less good research would be more likely to succeed in the second round of the proposed competition. And those which had the flair to spot new lines of promising research at an early stage, and the willingness to commit internal resources to their support, would be found to emerge with extra kudos from such competitions. So, properly handled, the grants committee's ambition to devise alternative criteria for assessing research support may turn out to provide two of the benefits conspicuous by their absence in recent years from the British system - internal mechanisms for deciding what backing should be given to what research, and opportunities by which institutions can improve their standing by their own wit. That such a system would also lend substance to the notion that universities are autonomous institutions even in the uncomfortable sense of that word is not the least of its attractions.

\section{Irish disunity}

\section{Bombs apart, Anglo-Irish talks are hopeful. Education deserves attention.}

THE unsuccessful attempt to assassinate the British cabinet last week will have one important and beneficent consequence - that of further stimulating the search for an accommodation between the governments of Ireland and the United Kingdom over the Ulster problem. By all accounts, the weeks preceding the bombing of the Brighton hotel in which four people were killed were cheerful times for the officials labouring on the details of an agreement. What seems to have happened, on the British side, is that one minister, Mr James Prior, has been replaced (at his own request) by another, Mr Douglas Hurd. In the nature of this, the most disheartening job in British politics, new policies require new men, who usually have only one chance at a solution. $\mathrm{Mr}$ Prior's chief initiative, the consultation between Irish politicians called a forum, was less successful than it might have been because of the absence of the Ulster nationalists and the intransigence of the Irish nationalists. Within the same framework, Mr Hurd appears to be putting his energy into the building of common institutions, the touchstone of Irish hopes two years ago.

While it is remarkable (but unremarked) that many Irish institutions (rugby football and the administration of lighthouses, for example) have survived Irish partition, it tends to be forgotten that Irish higher education has preserved many of the appearances of commonality. As European citizens, Irish students can enter British universities without paying the penal fees exacted from other foreigners, but the Irish Government will not help with maintenance costs. Roman Catholic students from Ulster tend to seek higher education south of the border, when they are welcomed as if Irish. There is the basis for a deal between the two governments on this trade in young people's aspirations, as well as for an understanding that, for the purposes of research, the two countries should count as one. That should be at least one part of the package of proposals Mr Hurd is hoping to have assembled by next month. 